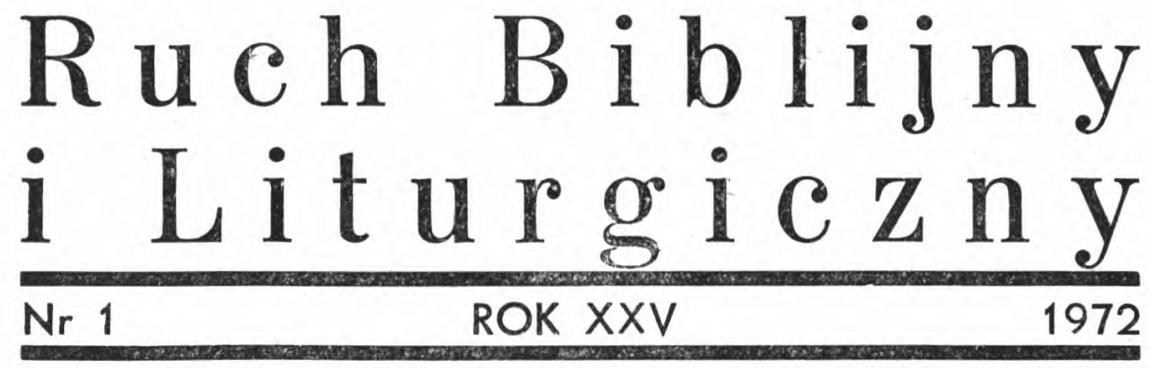

\title{
CZCIGODNY I DROGI KSIĘŻE REDAKTORZE!
}

Przed dwudziestu pięciu laty zaczął ukazywać się $w$ Krakowie Ruch Biblijny i Liturgiczny, którego założycielem i pierwszym redaktorem byt śp. Ksiadz Profesor Aleksy Klawek.

Myślę, że w ciagu tych dwudziestu pięciu lat organ Sekcji Biblijno-Liturgicznej Polskiego Towarzystwa Teologicznego dobrze zastużyt się nauce polskiej, nie tylko w środowisku krakowskim. Zwłaszcza zaś lata ostatnie, okres Soboru Watykańskiego II oraz odnowy biblijnej i liturgicznej, potwierdzity trafność inicjatywy sprzed dwudziestu pięciu lat.

W zwiazku z tym pragnę życzyć błogosławieństwa Bożego na dalsze lata stużby tej samej sprawie. Życzenia te składam na ręce Księdza Dziekana dla całej Redakcji $i$ Administracji oraz dla wszystkich Wspótpracowników czasopisma. Życząc dalszego rozwoju Ruchowi Biblijnemu i Liturgicznemu, życzę przez to samo rozległemu środowisku polskich biblistów i liturgistów jak najdojrzalszych owoców ich postannictwa w Kościele.

(一) Karol kard. Wojtyła 